\title{
Assessment of leaf spot and anthracnose diseases in nurseries and it relationship with oil palm seedling ages
}

\begin{abstract}
Survey of leaf spot and anthracnose diseases were conducted in nine selected oil palm nurseries in Peninsular Malaysia. Studies covered four nurseries in Johor (Kluang, Bkt.Tongkat, Kahang and Ayer Hitam), three nurseries in Perak (Teluk Intan, Permatang Guntung and Kg. Bakar Arang) and two nurseries in Selangor (Sepang and Kuala Langat). The symptoms of leaf spot and anthracnose diseases were recorded and characterized. In this study, the leaf spot and anthracnose diseases were found to be associated with three pathogens; they are Colletotrichum spp., Curvularia sp., and Pestalotiopsis sp. The disease survey revealed that leaf spot disease was a major problem in oil palm seedlings with the highest incidence was $62.8 \%$ compared to anthracnose disease at $16.5 \%$. For incidence of leaf spot disease, the highest were recorded in Kuala Langat, Selangor (90.3\%) and Kluang, Johor (87.7\%). The least incidences of leaf spot were recorded in three nurseries in Perak occurring between $50.0 \%$ to $55.0 \%$. For anthracnose disease, the highest incidence was recorded in Kuala Langat, Selangor (45.0\%) and the least were recorded in six nurseries which were located in Johor and Perak occurring between $8.0 \%$ to $14.0 \%$. For assessment of disease severity (DS), the highest for leaf spot disease were recorded in Kluang (64.7\%) and Kahang (59.2\%), both in Johor. Besides, the least severity was recorded in Permatang Guntung, Perak with 19.2\%. For DS of anthracnose disease, the highest were recorded in Kuala Langat, Selangor (9.1\%) and Teluk Intan, Perak (6.5\%) and the least DS were recorded in six nurseries which were located in Johor and Perak occurring between $1.0 \%$ to $2.5 \%$. The study also found disease incidence of leaf spot and anthracnose diseases were both highly significant with different age of oil palm seedlings. As the seedlings became older, incidence of leaf spot and anthracnose diseases were reduced. For leaf spot disease, seedling $<4$ months old, the highest score percentage at $77.4 \%$ followed by $4-12$ months old which was $72.8 \%$ and seedlings with age $>12$ month old were the lowest score of $49.0 \%$. This was similar with disease incidence of anthracnose for $<4$ months old (21.5\%), 4-12 months old $(16.8 \%)$ and with the least incidence was observed in seedlings aged $>12$ months old at $14.8 \%$. For interaction of seedling age with DS of leaf spot, study revealed that there were highly significant relationships with seedling ages. Seedling with age $<4$ months old were the most susceptible and severely affected (50.9\%) followed by seedling age 4-12 months old (39.8\%) and the most resistance seedling age was the seedling $>12$ months old with only $18.4 \%$. However, for anthracnose disease, there was no significant relationship between DS and seedlings ages.
\end{abstract}

Keyword: Leaf spot; Anthracnose; Oil palm; Disease severity; Disease incidence 